\title{
Lesser Included Offences, Alternative Offences and Accessorial Liability
}

\author{
Dennis J. Baker
}

\begin{abstract}
In this essay I shall examine when an alternative offence and also a lesser-included offence is available for an accessory. Particular reference will be made to the offences of manslaughter and murder. It shall be argued that the decision in $R$. $v$ Jogee and Ruddock $v$ The Queen is wrong as far as it holds that an accessory can be liable for manslaughter when the principal has been convicted of murder, because it is necessary to prove that the accessory intended the principal to perpetrate the actus reus of the relevant offence with the requisite mens rea for that offence. In such a scenario the accessory does not intentionally assist or encourage the more serious offence (murder), so she cannot be derivatively liable for it, and the principal does not perpetrate the less serious offence (manslaughter), so there is no offence of manslaughter for the accessory's liability to derive from. The accessory only attempts to assist or encourage the principal to engage in conduct that has the potential to form the conduct element of constructive manslaughter. Such a conviction would rest on a presumption of participation in a result crime, when no result was in fact caused by the non-perpetrated crime (manslaughter), but instead the result was caused by an alternative more serious crime (murder), which was in fact perpetrated. If the principal had done the actus reus that the accessory intended (i.e. unlawfully inflict a.b.h.), the victim most likely would not have been killed and it is pure speculation to suggest the victim could have been killed by a.b.h. as opposed to the act of grievous bodily harm (g.b.h.) or act of intentional killing, which in fact killed the victim. It shall be argued that in such cases it is best to prosecute the putative assister or encourager under sections 44 or 45 of the Serious Crime Act 2007, for attempting to assist or encourage a potential aggravated assault.
\end{abstract}

\section{Introduction}

In this essay I shall try to reconcile three themes. 1) The requirements set by the Supreme Court and the Board of the Judicial Committee of the Privy Council reinterpreting the mental element in complicity as requiring nothing less than intention. ${ }^{1}$ 2) The issues raised by what I shall call the 'alternative offence' rule. And, 3) The issues raised by the 'fundamental different act (offence?)' rule. The latter has been used as a maxim of evidence for inferring intention in common purpose complicity scenarios, but in light of the Supreme Court and the Board holding that the mental element in complicity is intention, it is important to consider whether the maxim has a wider application. It is a useful standard for excluding liability for the accessory for acts of the principal that were not intended and that were not the actus reus of a lesser-included offence, but can it also exclude potential liability arising from fundamentally different act situations where there is technically a shared intention as to the fault and actus reus elements of the anticipated target crime?

In the latter situation the maxim is problematic because it has been used to exclude liability for acts that form the actus reus (i.e. an act of g.b.h.) of the jointly

${ }^{1}$ R. v Jogee and Ruddock v The Queen [2016] 2 W.L.R. 681 at 704-705. The Supreme Court of the United States also has held that mental element in complicity is intention and nothing less. Rosemond v U.S. (2014) 134 S.Ct. 1240. 
intended collateral offence (for example, constructive murder), that are fundamentally different acts (means) for inflicting g.b.h. For example, an act of stabbing is fundamentally different from punching a person with a bare fist-but both actions/means could be used to inflict g.b.h. Any application of the fundamental different act rule has to be reconciled with the mental element in complicity, which requires intention on the accessory's part, because the Supreme Court and Board have held that the rule still has a role to play. ${ }^{2}$ In recent decades the rule has worked more as an evidential maxim and has been used to exclude an inference of fault for complicity in joint enterprise scenarios when a principal completely departed from what was intended by the parties to the underlying joint enterprise and perpetrated a collateral offence that was not intended nor foreseen ${ }^{3}$ by the accessory. ${ }^{4}$ There is no doubt that it is an evidential tool for inferring that the collateral offence perpetrated by the principal was not one that the accessory intended the principal to perpetrate, because it was different from what the accessory intended as a potential collateral offence.

The 'fundamental different act' maxim and the intention requirement will be difficult to reconcile where the result ${ }^{5}$ of the different acts are intended by all parties to be the same (e.g., all parties intend the result of g.b.h., but not the consequence of death), but the principal departs from the common intention and perpetrates an act of g.b.h. that is inherently more likely to cause the victim's death (i.e. stabbing V in the throat instead of kneecapping her) and that act has the unintended consequence of causing the victim's death. ${ }^{6}$ Technically, in such cases, all parties should be liable for murder because the principal has perpetrated the actus reus (the principal has inflicted g.b.h. which has caused V's death) of the offence of (constructive) murder with the requisite fault (intending to inflict g.b.h.) and the accessories have assisted and encouraged intending the principal to inflict g.b.h. The only difference in such cases is that the principal has used inherently lethal actions/means to inflict the g.b.h., but the principal has perpetrated the actus reus for murder with the requisite fault and that is what the accessories technically intended. One way to resolve the conflict would be to abrogate the offence of constructive murder, but that is unlikely to happen for some time. ${ }^{7}$ Nonetheless, the fundamental different act rule can still be invoked in such cases. ${ }^{8}$ In this sense, it is used as a doctrinal constraint on liability rather than merely as an evidential maxim for inferring intention.

The fundamental different act rule and the alternative offence rule need careful consideration, because in R. v Jogee and Ruddockv The Queen, ${ }^{9}$ the Supreme Court and the Board held that for centuries the English law of complicity required

\footnotetext{
2 R. v Jogee and Ruddock v The Queen [2016] 2 W.L.R. 681 at 707F-G.

3 The recklessness fault element applied in R. v Bryce [2004] 2 Cr. App. R. 592 at 611 per Potter L.J; R. v Powell [1999] 1 A.C. 1, was abrogated by R. v Jogee and Ruddock v The Queen [2016] 2 W.L.R. 681.

${ }^{4}$ Dennis J. Baker, Reinterpreting Criminal Complicity and Inchoate Participation Offences, (Oxford: Routledge, 2016) at 49-55; 69-85.

${ }^{5}$ von Wright writes: 'The connection between an action and its result is intrinsic, logical and not causal (extrinsic). If the result does not materialize, the action simply has not been performed. The result is an essential 'part' of the action. It is a bad mistake to think of the act(ion) itself as a cause of its result.' Georg Henrik von Wright, Explanation and Understanding, (Oxford: Routledge, 2011) at 67-68.

${ }^{6}$ Cf. R. $v$ Gamble [1989] N.I. 268. On when intending the actus reus of a constructive crime is and is not sufficient, see Brown v. State (1887) 11 N. E. 447 (1887); Thomas v. Commonwealth (1905) 27 Ky. L. Rep. 794, R v. Gaylor (1857) 7 Cox, C. C. 253.

7 If constructive murder were abrogated, the accessories would be liable for an inchoate act of attempting to encourage contrary to the Serious Crime Act 2007, because they tried to encourage an assault that was meant to result in g.b.h., but the principal might be liable for murder if the evidence is sufficient for the jury to infer from the fundamentally different act of stabbing $\mathrm{V}$ in the throat that the principal intended or obliquely intended to kill $\mathrm{V}$.

8 R. v Jogee and Ruddock $v$ The Queen [2016] 2 W.L.R. 681 at 693; 701; 707.

${ }^{9}$ [2016] 2 W.L.R. 681 at 704.
} 
nothing less than intention. Lord Toulson and Lord Hughes held that the ancient and modern authorities right up until the decision in Chan Wing-Siu $v$ The Queen ${ }^{10}$, showed that the mental element in complicity was intention. It also has been held that there is no such thing as joint enterprise complicity, because the actus reus in all complicity has to be either an act of encouragement or an act of assistance and that this is expressly stated in section 8 Accessories and Abettors Act 1861, which was merely declaratory of the common law. ${ }^{11}$

Following $R v$ Jogee the mens rea for complicity liability is intention. D must intend to assist or encourage $\mathrm{P}$ with the ulterior intention that $\mathrm{P}$ use his or her assistance (or be encouraged by his or her encouragement) to perpetrate the anticipated target crime. Foresight is evidence for inferring intention and nothing more. Foresight of virtual certainty is required for inferring intention ${ }^{12}$, but evidence of any degree of foresight might be relevant for ascertaining foresight of contingencies in the context of conditional intention. Hence, it does not matter that D only foresaw that there was a $10 \%$ chance that $\mathrm{D}$ and $\mathrm{P}$ might be interrupted by a security guard whilst jointly perpetrating a burglary, as long as D foresaw the virtually certain response from $\mathrm{P}$ upon that contingency arising (a security guard approaching them) was that $\mathrm{P}$ would use lethal force.

Section 8 of the Act of 1861 requires factual assistance and/or encouragement, not mere association. The foresight rule in complicity was simply a rule of evidence for inferring intention in joint enterprise (common purpose) complicity scenarios. ${ }^{13}$ It was judicial carelessness ${ }^{14}$ that resulted in it being adopted as a substantive fault element for both common purpose complicity scenarios and also for straightforward cases of assistance and encouragement. Common purpose complicity is just another way of participating in a crime by encouraging it. Its actus reus is encouragement contrary to section 8 of the Act of 1861 . This type of complicity scenario only looks like a different form of complicity, because the act of intentional encouragement has to be inferred from the circumstances of the joint enterprise. Hence, the conduct of participating in the underlying joint enterprise itself may or may not form an act of intentional encouragement in relation to any collateral offences, depending on what the parties mutually and conditionally intended.

\footnotetext{
10 ' $\mathrm{U}]$ ntil the decision in the House of Lords in R. $v$. Powell changed the law, the foresight of possibility rule (i.e., the accessory's foresight of the collateral crime as a possible incident of the underlying joint enterprise), like the probable and natural consequences maxim, was a mere maxim of evidence for inferring that the common purpose extended to the collateral crime. .... I will focus on the rules that have been developed for allowing a jury to infer intention and reckless foresight for the purpose of establishing common purpose complicity. These same rules were traditionally used for inferring intention, but in recent decades they have also been used to infer reckless foresight in common purpose complicity cases. What was a maxim of evidence has been invoked as a substantive fault element in complicity since 1999, which has had the effect of extending the mental element in common purpose complicity to cover recklessness. Traditionally, the maxim that a person intends the foreseen consequences of her actions was used in common purpose complicity only to infer that the accessory authorized and thus intended or conditionally intended to encourage the perpetrator to perpetrate the (conditional) collateral crime. A crime as a foreseen collateral crime of an underlying joint enterprise was merely evidence from which an accessory's intention or conditional intention that the perpetrator perpetrate the collateral crime could be inferred. Foresight was not a substantive fault element, but merely a maxim of evidence.' Dennis J. Baker, Glanville Williams: Textbook of Criminal Law (London: Sweet \& Maxwell, 2015) at para. 17-069. The Lords seemed to have been influenced by this argument. In R v Jogee and Ruddock v The Queen [2016] 2 W.L.R. 681 at 705F, Lords Toulson and Hughes said: 'The error was to equate foresight with intent...' See also the foreword by Lord Toulson, in Baker, above n. 4.

${ }_{11}$ R. v Jogee and Ruddock v The Queen [2016] 2 W.L.R. 681. See also Giorgianni v The Queen, where Gibbs CJ said: "Section ... 8 of the Accessories and Abettors Act 1861 (U.K.) ... [as] has often been said, was only declaratory of the common law on the subject." See also Rosemond v U.S. (2014) 134 S.Ct. 1240.

${ }^{12} \mathrm{R} v$ Woollin [1999] AC 82.

${ }^{13}$ Dennis J. Baker, 'Reinterpreting the Mental Health in Criminal Complicity: Change of Normative Position Theory Cannot Rationalize the Current Law,' (2016) 40 Law \& Psychol. Rev. 1-130.

${ }^{14}$ R. v. Bryce [2004] 2 Cr. App. R. 592 at 611 per Potter L.J; R. v. Powell [1999] 1 A.C. 1.
} 
In R. v Jogee and Ruddockv The Queen, Lords Toulson and Hughes held that the poaching cases ${ }^{15}$ and an ancient line of cases dealing with facts where conditional intention was an issue supported interpreting the mental element in complicity as requiring nothing less than intention. ${ }^{16}$ Following the decision of the Supreme Court and Board, there will have to be strong evidence of a common or shared purpose extending to the collateral crime, before a jury could infer that the accessory had it as her purpose to encourage the principal to perpetrate the collateral crime. Hence, foresight is mere evidence for inferring intention in joint enterprise scenarios and there is no separate form of complicity with association as its actus reus. ${ }^{17}$ The reasoning provided by Court and Board in support of reinterpreting the mental element in complicity is convincing and is supported by academic research. ${ }^{18}$

The only sound reason for finding that complicity requires intention is to be found by examining the complicity cases dealing with common purpose scenarios; ${ }^{19}$ particularly those that dealt with conditional intention scenarios. The conditional intention cases best exemplify that foresight was used in joint enterprise scenarios only as evidence of a shared intention or a common purpose. ${ }^{20}$ Foresight was used as evidence of intention in those cases, not as evidence of recklessness because the mental element required a common intention with respect to the collateral crime. ${ }^{21}$ It is those cases that best support a finding that the mental element in complicity is intention and, to the extent the judgment relies on those cases, it is legally unassailable. $^{22}$ Foresight was relevant for considering not only issues arising with foreseen collateral crimes that were contingent on some intervening event, such as the intervention of a guard during a burglary, but also with respect to what the accessory intended the principal to do upon such a contingency arising. What is clear is that the law now requires that the accessory must not only intend to assist or encourage, but must do so with the ulterior intention that her assistance or encouragement in fact assist or encourage the principal to perpetrate the mutually anticipated target crime.

There is no doubt that the Supreme Court and the Board has reinterpreted the mental element in complicity as requiring nothing less than intention. Under the heading "Restatement of the principles", Lord Toulson and Lord Hughes held:

'the accessory [must intend] to encourage or assist D1 to commit the crime, acting with whatever mental element the offence requires of D1 ... If the crime requires a particular intent, D2 must intend (it may be conditionally) to assist D1 to act with such intent.'23

\footnotetext{
${ }^{15}$ For a very detailed and extended examination and analysis of the poaching cases, see Baker, above note 4 at Chap. 2. ${ }^{16}$ R v Jogee and Ruddock v The Queen [2016] 2 W.L.R. 681 at 703H. Cf. Alexander F. Sarch, 'Condoning the Crime: The Elusive Mens Rea for Complicity' (2015) 47(1) Loy. U. Chi. L.J. 131; Shachar Eldar, 'Examining Intent through the Lens of Complicity' (2015) 28 Can. J. L. \& Jurisprudence 29.

${ }^{17}$ Cf. the erroneous finding to the contrary by the majority of the High Court of Australia in Miller v The Queen [2016] HCA 30.

18 These arguments were presented in academic research, which the Court and Board considered. Lords Hughes and Toulson said: 'we have had the benefit of a much fuller analysis than on previous occasions when the topic has been considered.' R v Jogee and Ruddock, v The Queen [2016] 2 W.L.R. 681 at 704 C.

${ }^{19}$ Baker, above note 4 at Chap. 2.

${ }^{20}$ Ibid.

${ }^{21}$ Ibid.

22 Ibid.

${ }^{23}$ The Lords go on to state: 'However, as a matter of law, it is enough that D2 intended to assist D1 to act with the requisite intent. That may well be the situation if the assistance or encouragement is rendered some time before the crime is committed and at a time when it is not clear what D1 may or may not decide to do.' R. $v$ Jogee and Ruddock $v$ The Queen [2016] 2 W.L.R. 681 at 706B-D.
} 
'In cases of secondary liability arising out of a prior joint criminal venture, it will also often be necessary to draw the jury's attention to the fact that the intention to assist, and indeed the intention that the crime should be committed, may be conditional. $^{\text {,24 }}$

\footnotetext{
'Juries frequently have to decide questions of intent (including conditional intent) by a process of inference from the facts and circumstances proved. ... A time honoured way of inviting a jury to consider such a question is to ask the jury whether they are sure that D1's act was within the scope of the joint venture, that is, whether D2 expressly or tacitly agreed to a plan which included D1 going as far as he did, and committing crime $\mathrm{B}$, if the occasion arose. 25
}

The new strict intention requirement leaves no room for recklessness to be considered as an alternative mental element in complicity. I want to stress this point, because it has implications for the thesis presented in this essay, which is that a strict intention requirement leaves no room for an accessory to be convicted of an alternative offence unless it is strictly a lesser-included offence. ${ }^{26}$ I shall argue that manslaughter is not a lesser-included offence for murder and thus an accessory cannot be convicted of manslaughter when the principal has been convicted of the alternative offence of murder. Williams argued: ${ }^{27}$

'An included offence normally has a wider definition than the offence charged (if all the implied elements of both offences are taken into account). This is because the included offence either lacks a matter of aggravation in the offence charged or requires a mitigating circumstance or a mitigated fault element. Manslaughter is the chief example of the latter group; it can include the mens rea required for murder, but only if special mitigations (provocation or diminished responsibility) are present; otherwise it requires a lesser fault element. It became an included offence as a result of faulty reasoning on the part of the judges; because of its special features it is separately dealt with in the Criminal Law Act 1967, s 6, and should now be regarded not as an included offence but as an alternative verdict...'

The new straightforward fault element is: 1) D1 is derivatively liable if she intentionally and voluntarily does an act that assists or encourages another to perpetrate a crime. The act of assistance or encouragement would not be intentional and voluntary if it was done under duress ${ }^{28}$ or while D1 was in a state of automatism. Thus, if D1 uttered in her sleep 'D2 I want you to kill V,' it could hardly be said that D1 had acted voluntarily and intentionally. 2) D1's intentional act of assistance or encouragement must be done with an ulterior intention that it assist or encourage D2 to perpetrate the anticipated target offence. D1 has to intend that D2 be encouraged or assisted to perpetrate the actus reus of the anticipated target offence and that D2 act with the requisite fault for that offence. When the accessory is indicted for murder for intentionally assisting or encouraging the principal to kill with an ulterior intention

\footnotetext{
${ }^{24}$ R. v Jogee and Ruddock v The Queen [2016] 2 W.L.R. 681 at 706F.

${ }^{25}$ R. v Jogee and Ruddock $v$ The Queen [2016] 2 W.L.R. 681 at 706G.

${ }^{26}$ In R. v JB [2013] EWCA Crim. 356, Hughes LJ (as he then was) conflates lesser-included and lesser alternative offences. For a fuller discussion of lesser-included offences see: Michael H. Hoffheimer, 'The Rise and Fall of Lesser Included Offenses, (2005) 36(2) Rutgers L.J. 351.

${ }_{27}$ Glanville Williams, "Included Offences", (1991) 55 J. Crim. L. 234 at 234-235.

${ }^{28}$ However, an agent under duress will not have a defence to murder, since the defence is not available to the principal. R. v Howe [1987] A.C. 417; cf. R. v Bourne (1952) 36 Cr. App. R. 125.
} 
that the principal act with the requisite fault for murder, the accessory's ulterior intention relating to the principal's mens rea and actus reus for murder is material. ${ }^{29}$

In the days when manslaughter was regarded as a lesser-included offence for murder and when recklessness was used as an alternative fault element for murder, the courts did allow for alternative convictions, ${ }^{30}$ but since these conceptualizations of murder and manslaughter are now obsolete such an approach does not hold water. Writing in the 1950s, Turner took the view that the mental element for murder was an intention to kill or cause g.b.h. or alternatively subjective foresight that one's act might expose a person to harm that could cause her death. ${ }^{31}$ In addition, Turner argued that the mental element for involuntary manslaughter was subjective foresight that one's unlawful act might expose the victim to the risk of suffering g.b.h. ${ }^{32}$ Williams has observed, "For many years the authorities were discordant on the question of whether recklessness (as to death or g.b.h.) was sufficient for murder., 33 In 1960s, the House of Lords even went as far as holding objective negligence was sufficient fault for murder. ${ }^{34}$ Thereafter, in 1970s the House of Lords took the view that subjective risk-taking was sufficient mens rea for murder. ${ }^{35}$ Notwithstanding the confusion of earlier times, it is now clear that manslaughter and murder are alternative offences with different mentes reae elements and actus reus elements. ${ }^{36}$ Therefore intending a person perpetrate manslaughter does not include an intention that murder be perpetrated, nor vice versa.

In the next two sections of this essay, I want to limit my discussion of $R v$ Jogee and Ruddock $v$ The Queen to the issue concerning whether manslaughter can be available when an accomplice perpetrates a collateral murder during the course of a joint enterprise. I shall start by examining the fundamental different act rule in that context. I shall try to defend the following thesis: If the mental element in complicity is intention, then that should mean that those who do not intend to assist or encourage with the ulterior intention that their assistance be used by the principal to perpetrate the anticipated target offence or that their encouragement encourage the principal to

\footnotetext{
${ }^{29}$ Compare Harper v. Com. (2001) 43 S.W.3d 261; U.S. v. LaPointe (2012) 690 F.3d 434; Potts v State (1981) 403 So $2 \mathrm{~d}$ 443.

${ }^{30}$ See Murray v The Queen [1962] Tas SR 170 (Austl. Tas.) per Burbury CJ and Gibson J; Crawford J. dissentiente. See the discussion in Glanville Williams, Criminal Law: The General Part (London: Stevens \& Sons, 2nd edn 1961) at 94-99; J.W.C. Turner, 'The Mental Element in Crimes at Common Law' in L. Radzinowicz and J.W.C. Turner (Eds), $A$ Modern Approach to Criminal Law (London: Stevens \& Sons, 1947) at 195. Hart has remarked: 'Older legal writers extend the use of the word "intentionally" to cases where the consequences are thought likely, and reserve "recklessly" for the cases where a man does not assess the consequences as likely. But this semantic dispute is often very barren, since those who insist on the narrower use of intention agree, even if regretfully, with the advocates of the wider use, that under the existing law it is usually enough for criminal liability that the consequences were thought likely, so that the distinction they draw between "intentionally" and "recklessly" is at present in most cases immaterial.' Hart, Punishment and Responsibility, (Oxford: Clarendon Press, 1968) at 117.

31 J.W.C. Turner, Russell on Crime (London: Stevens \& Sons, 11 th edn 1958) Vol. I at 528.

32 Id. at 659.

33 Glanville Williams, Textbook of Criminal Law, (London: Stevens \& Sons, 1978) at 213-218.

${ }^{34}$ DPP $v$ Smith [1961] AC 290. Howard, the leading authority on criminal law in Australia at the time, took the view that the English law at that time allowed for a murder conviction where the victim's death resulted from reckless g.b.h. rather than intentional g.b.h. See Colin Howard, Criminal Law (Sydney: The Lawbook Company Ltd., $3^{\text {rd }}$ edn 1977) at 45. For centuries judges tried to guess what went through the defendant's mind without accepting evidence from the defendant. "[T] he objective test did not define the relevant intention as to the consequences of a voluntary act. It was no more than one means of ascertaining the relevant intention, to which the Criminal Evidence Act 1898 added another-the defendant's own evidence of what his actual intention was." Hyam v. DPP [1975] A.C. 55, 94. Before the enactment of the Criminal Evidence Act 1898, D was not allowed to testify as to what his or her intention was." Nonetheless, the old rule had no effect on the substantive fault doctrine that exited before 1898 - the Act of 1898 only allowed for D's evidence to be added to all the other evidence to assist the court in determining whether D had the requisite mens rea.

${ }^{35}$ Hyam v DPP [1975] A.C. 55.

36 See People v. Grissom, No. 00CA1407, slip op. at 10-12, 2003 WL 22113721 (Colo.App.2003).
} 
perpetrate the anticipated target offence, should not be liable for any alternative crime that is not a lesser-included offence.

If D1 assists or encourages and intends or obliquely intends his or her assistance or encouragement to assist or encourage D2 to perpetrate unlawful conduct (inflict a.b.h.) that could form the actus reus of constructive manslaughter depending on whether it causes V's death, D1 could be caught by section 44 or alternatively section 45 of the Serious Crime Act 2007 (sections 44 and 45 catch inchoate assistance and encouragement and thus a fortiori catch consummated assistance and encouragement - something that is often overlooked by barristers), ${ }^{37}$ but D1 should not be derivatively liable for manslaughter if D2 has deliberately departed from the shared intention which was to inflict a.b.h., and instead, killed or inflicted g.b.h. When D2 departs from the plan, all we know for sure is that D1 attempted to assist or encourage assault contrary to section 47 of the Offences against the Person Act 1861. Such an assault might or might not have resulted in constructive manslaughter being perpetrated, but since the assault was not perpetrated we have no way of knowing whether it would have killed V. Hence, since a.b.h. is not inflicted, but instead g.b.h. or worse is inflicted, there is no way of knowing whether had D2 not departed from the plan, the collateral offence would have been assault contrary to section 47 of the Act of 1861 or constructive manslaughter-it is all guesswork, because D1's wrong did not get past the attempt stage. What we know for sure is that D1 attempted to assist or encourage an assault, so it is safe to invoke the inchoate offences found in the Serious Crime Act 2007.

\section{Manslaughter as an Alternative: Causation and the Missing Derivative Link}

There are ancient cases that allowed for an alternative manslaughter conviction for the accessory when the principal had been convicted of murder. These cases seem to rest on the simple doctrinal premise that murder and manslaughter emerged from a single felony and the elements of those offences were conflated. A classic application of the now obsolete 'lesser included' (conflated offence) approach can be found in Thody's case. ${ }^{38}$ While the decision by Holt, C.J. in Trial of Lord Mohun ${ }^{39}$ is sometimes cited in support of rule that an accessory can be convicted of manslaughter when the principal has been convicted of murder, a careful reading of that case shows it supports the fundamental different act rule, not the alternative offence rule. All the examples and reasoning given in Holt CJ's judgment ${ }^{40}$ support holding that actual intention is required for an accessory to be liable for the perpetrator's crime and that the accessory should be derivatively liable only for the specific crime she intended to assist or encourage.

It is important to note that these old cases rest on an obsolete conception of the offences of murder and manslaughter being a single felony and on an obsolete

\footnotetext{
${ }^{37}$ Dennis J. Baker, 'Conceptualizing Inchoate Complicity: The Normative and Doctrinal Case for Lessor Offenses as an Alternative to Complicity Liability,' (2016) 25(1) S. Cal. Interdisc. L.J. 503-587.

38 (1673) Freem. K.B. 514, where Freeman reported: 'It was delivered for law by the whole Court, that if two persons of a side engage in a quarrel, and each of them singles out his adversary, and one of them is killed; as well the companion of him that killed the other, as he himself, is guilty of the manslaughter; and if they came with malice prepensed, they are both guilty of murder; and if he that killed him came with malice prepensed, and the other not, the one is guilty of murder, and the other of manslaughter; and so Thody was found guilty of manslaughter, though his brother killed Blunfield of Gray's Inn with a tobacco-pipe, wherewith he struck him in the eye.'

39 (1692) Holt K.B. 479. See also R v Skeet (1866) 4 Fost \& F 931.

40 (1692) Holt K.B. 479 at 480-481.
} 
understanding of malice aforethought. Our contemporary definitions of murder and manslaughter and the fault and conduct elements for those offences mean that it is an error to use one as an substitute for the other-simply because the accessory was attempting to assist or encourage the lesser offence when the principal departed from the plan and perpetrated a more serious offence. The obiter statements of Hilbery J, in the often-cited case of $R v$ Murtagh and Kennedy ${ }^{41}$, do not provide a convincing nor reasoned justification for accepting an "alternative offence" rule. Such a rule cannot be reconciled with intention as the mental element in complicity or with a derivative conceptualization of accessorial liability.

In $R v$ Lovesey, Widgery LJ took the view that the common intention requirement precluded an alternative conviction for manslaughter. ${ }^{42}$ The decision in $R$ $v$ Lovesey was endorsed by the House of Lords in $R$. $v$ Powell, but the decision in $R v$ Jogee and Ruddock $v$ The Queen, at least on this point, adopts the reasoning of the trial judge in $R v$ Betty. ${ }^{43}$ Lords Toulson and Hughes said: ${ }^{44}$

\begin{abstract}
'If a person is a party to a violent attack on another, without an intent to assist in the causing of death or really serious harm, but the violence escalates and results in death, he will be not guilty of murder but guilty of manslaughter. So also if he participates by encouragement or assistance in any other unlawful act which all sober and reasonable people would realise carried the risk of some harm (not necessarily serious) to another, and death in fact results... [I]f a person goes out with armed companions to cause harm to another, any reasonable person would recognise that there is not only a risk of harm, but a risk of the violence escalating to the point at which serious harm or death may result. Cases in which D2 intends some harm falling short of grievous bodily harm are a fortiori, but manslaughter is not limited to these.'
\end{abstract}

If their lordships were referring to a joint act where both parties have different mental states, then the law of complicity would have been irrelevant because both parties would have been personally rather than derivatively liable. ${ }^{45}$ So if D1 and D2 jointly push V out of the back of a slow moving motorcar, where D1 only intends a.b.h. and D2 intents g.b.h., they could be liable for manslaughter and murder respectively, if their joint act of simultaneously pushing $\mathrm{V}$ out of the moving van is the cause of V's death. Their joint act of pushing is the direct cause of V's death. This is a case of joint perpetration of an actus reus that is the same for two different result crimes (i.e., causing death is the prohibited act for both manslaughter and murder) with their different mentes reae making them liable for different crimes, not a case of principal and accessory. It is fairly clear that their lordships were not referring to a jointly perpetrated act that could form the actus reus of more than one crime; after all the main authority they cite in support of their alternative offence rule is the decision in R. $v$ Reid ${ }^{46}$ where there was clearly no joint act of perpetration.

\footnotetext{
41 (1955) 39 Cr. App. R. 72.

${ }^{42} \mathrm{R} v$ Lovesey $[1970] 1$ Q.B. 352 at $556 \mathrm{H}$.

43 (1964) 48 Cr. App. R. 6 at 10.

44 [2016] 2 W.L.R. 681 at 707D-E.

${ }^{45}$ Dennis J. Baker, 'Mutual Combat Complicity, Transferred Intention/Defences and the Exempt Party Defence' (2016) 37 U. La Verne L. Rev. 101 at 137-144.

46 'Reid and two others were tried for the murder of a colonel who was the commander of an army training camp. The three men were alleged to be supporters of the IRA. They went to the colonel's house in the early hours of the morning and rang the doorbell. The door was opened by the colonel, and one of the other defendants immediately shot him dead. The other two men were convicted of murder and Reid was convicted of manslaughter. ... Reid's defence was that he ... went with the others as an interested but innocent spectator with no intention of causing any harm. The jury must have ... accepted it as possible that he did not intend the victim to suffer death or serious harm.'
} 
Intention as the mental element in complicity ${ }^{47}$ cannot be reconciled with an alternative offence rule that allows for a manslaughter conviction when a principal has been convicted of murder. ${ }^{48}$ Furthermore, the Court's and Board's endorsement of the fundamental different act (offence) rule cannot be reconciled with the alternative offence rule. $R v$ Jogee and Ruddock $v$ The Queen ${ }^{49}$ changed the law by accepting that the mental element in complicity requires nothing less than intention. The corollary of having intention as the mental element in complicity means a person can only be liable for the actual offence she intended the principal to perpetrate and only if the principal perpetrates that exact offence or a lesser included offence. Since manslaughter is not a lesser-included offence of murder, a person cannot be liable for manslaughter when the principal has been convicted of murder.

Recently, the High Court of Australia said: 'Professor Williams, ... observes that manslaughter is not correctly classified as an included offence. He suggests that its separate treatment as an alternative verdict under s 6(2) of the Criminal Law Act 1967 (UK) reflects the special features of the verdict of manslaughter. ${ }^{50}$ Historically, murder and manslaughter were a single felony, ${ }^{51}$ so it was not implausible to return a conviction for manslaughter for the accessory even where the principal had been convicted of murder.

\begin{abstract}
'By statutes passed in 1496, 1512, 1531 and 1547 benefit of clergy was progressively denied to homicides committed of malice aforethought. The last of these (1 Edw. 6 c. 12) excluded benefit of clergy from every felonious killing done ex malitia praecogitata. .... It is upon these statutes that the distinction between murder and manslaughter rested. They did not provide a new crime. What they did was, in effect, to make capital the felony of homicide when committed with a particular kind of mens rea.... What is more important, it was never doubted that an indictment for murder must allege the malice aforethought. If it alleged the felony merely, it amounted to a charge of clergyable homicide, namely manslaughter. .... $[T]$ he difference between murder and manslaughter was not the difference between two distinct felonies, but the difference between two descriptions of the one felony. They were differentiated only because the consequences of a conviction had, by statute, ceased to be the same. But the fact that the two descriptions formed only one felony is reflected in one consequence which profoundly affects the practical conduct and often the result of a murder trial of today. For it is because homicide is a single felony, that, upon an indictment of murder, a verdict of manslaughter may be found. ${ }^{52}$
\end{abstract}

\footnotetext{
... "'If such injury was not intended by the others, they must be acquitted of murder; but having started out on an enterprise which envisaged some degree of violence, albeit nothing more than causing fright, they will be guilty of manslaughter."' R. v Jogee and Ruddock v The Queen [2016] 2 W.L.R. 681 at 693-694, 703A-B citing R. v Reid (1976) 62 Cr App R 109.

47 [2016] 2 W.L.R. 681 at 693 at 691, Lords Toulson and Hughes hold: 'It will be seen that the expression "common design" is here treated as synonymous with shared intention.'

48 [2016] 2 W.L.R. 681 at 693.

49 [2016] 2 W.L.R. 681.

50 James v The Queen [2014] HCA 6 per French, CJ, Hayne, Crennan, Kiefel, Bell, and Keane, JJ at para..

51 'Felony is a feudal conception particularly applying to the breach of the fidelity and loyalty which should accompany the feudal relationship which has been consecrated by homage. Its characteristic punishment is therefore loss of tenement-escheat. On the continent felony was often confined to this class of crime, but in England, by means unknown, there came "a deep change in thought and feeling. All the hatred and contempt which are behind the word felon are enlisted against the criminal, murderer, robber, thief, without reference to any breach of the bond of homage and fealty." The transition may have been helped by the fact that already in Anglo-Saxon law there were crimes which put their author at the absolute mercy of the King, their property, limb and life. The King's "great forfeiture" may thus have caused these crimes to be equated with true felony which resembled it.' Theodore F. T. Plucknett, A Concise History of the Law (London: Butterworth \& Co. Ltd., 5th ed., 1956) at 442.

52 'The middle of the thirteenth century provides an early enough beginning. By that time the characteristics of felony have been ascertained. An accuser, if he be ready to offer battle, can bring an appeal of felony. The felon's lands escheat and his chattels are forfeit. He is punished by loss of life or member. If he flees he is outlawed. The chief felony is homicide. The distinction between murder and manslaughter is unknown. The very word "murdrum" does not, in its legal use, signify the crime. It is the name of the fine levied upon the hundred which fails to produce the slayer and fails to establish the Englishry of the slain. ... Not only is the distinction between murder and manslaughter
} 
Professor Plucknett notes the effect of pardons on the early emergence of various forms of homicide as follows: "It is important to remember that the prerogative of mercy was the only point at which our mediaeval criminal law was at all flexible; hence pardons were issued with liberality for all sorts of felonies throughout the middle ages and long afterwards, and it is in the history of pardons, therefore, that the gradual growth of a classification of homicides is to be sought.", 33

The $R v$ Jogee approach is not available for offences that are alternative offences rather than lesser-included offences. Manslaughter is an alternative offence, not a lesser-included offence. This is expressly stated in section 6 of the Criminal Law Act 1967. Section 6 clears up any uncertainty as to whether manslaughter is a lesserincluded offence by expressly stating it is an alternative offence. ${ }^{54}$

It is true that a jury can return an alternative conviction of manslaughter for a perpetrator, when it is sure that evidence supports a manslaughter conviction, but not a murder conviction. ${ }^{55}$ This works well against the doer, but applying the alternative offence rule to personal liability cases is different from applying it to derivative liability cases. If the accessory shares the principal's intention with respect to the elements that form the manslaughter offence, then she will be equally liable. However, it is one thing to hold an accessory liable for manslaughter when she and the principal's common intention was that the principal inflict a.b.h. upon $\mathrm{V}$ and this had the unintended consequence of killing $\mathrm{V}$, but something entirely different to hold her liable when that offence has not been perpetrated, but instead the principal has departed from the plan and perpetrated a murder.

Derivative liability becomes fictitious in such cases, because it rests on the fiction that because D1 was participating in the underlying offence and intended as well as attempted to encourage D2 to perpetrate the actus reus of the potential collateral offence of assault contrary to section 47 of the Offences against the Person Act 1861, D1 should be punished for the greater offence of constructive manslaughter, because an alternative collateral offence was perpetrated and it caused the victim's death. The rationale for punishment seems to be based on a theory of transferred

unthought of, but all killing is a crime unless it is, in effect, done in the execution of justice.' Sir Owen Dixon, 'The Development of the Law of Homicide", in Jesting Pilate: and Other Papers and Addresses, (Sydney: Law Book Co., 1965) 61 at 65. At 63, Sir Owen Dixon argues that "the Statute of Gloucester (6 Edw. 1 c. 9 [enacted in 1278)] ... forms the foundation of the development of the law of excusable homicide." Coldiron observes, "Staundford should be noted particularly because he divided or contrasted "homicide par chance medley" and "homicide par voy de murder." In the phrase 'chance medley' lie the roots of the present-day elements of 'sudden heat and passion' and provocation which were later to distinguish manslaughter from murder.' William H. Coldiron, 'Historical Development of Manslaughter', (1949) 38 Ky. L.J. 527 at 533. However, Staundford seemed to be using 'chance medley' to refer to accidental killings, where later the doctrine was applied more usually in the context of deaths resulting from sudden brawls and thus was used as a partial excuse to reduce murder to manslaughter. See William Staunford, Les Plees del Coron (London: by Rychard Tottel, 1567) at 18b. See Mansell and Herbert's Case (1555) 2 Dyer 128; cf. Salisbury's Case (1553) 1 Plow. 97. See also J. M. Kaye, 'The Early History of Murder and Manslaughter, Part II', (1967) 83 L.Q.R. 569 at 575 referring to the tripartite distinction drawn by Sir Richard Elyot. See Ferdinando Pulton, De pace Regis et regni (London: Printed for the Companie of Stationers, 1610) at 120.

${ }^{53}$ Plucknett, above note 51 at 445. See also James Fitzjames Stephen, A History of the Criminal Law of England (London: Macmillan, 1883) Vol. 3 at 36-41. Stephen, id. at 44, writes: "Up to this time [the period 1496-1548] it appears from what has been already said that though there may be said to have been a legal definition of murder as distinguished from other forms of homicide it was a distinction which made hardly any difference, for all homicide, unless it was justifiable, se defendendo or by misadventure, was felonious and so punishable with death, and was also within benefit of clergy whether it did or did not amount to murder. Thus the only distinction between murder and what we should now call manslaughter, consisted in the fact that murder by way-laying, assault, or malice prepense was not within the terms of any general pardon."

${ }^{54}$ The leading practitioner textbook treats murder and manslaughter as alternative crimes. See Arcbbold, Criminal Pleading, Evidence and Practice, (London: Sweet \& Maxwell, 2016) at paras. 4-532 and 19-106.

55 The alternative conviction is an acquittal for murder and a conviction for manslaughter. R. v JB [2013] EWCA Crim 356 at para. 10. 
liability: liability transfers from the collateral offence perpetrated to the one that could have been perpetrated to convict the accessory of an alternative offence that could have been perpetrated, but which was not perpetrated. It seems that that the judges have some sort of change of normative position ${ }^{56}$ justification in mind. The judges seem to be rationalizing this approach by holding that the accessory by jointly perpetrating the underlying offence with an intention that a collateral offence be perpetrated that could have had the same result as the alternative collateral offence did in fact have, makes it fair to punish her for the potential collateral crime that was not in fact perpetrated. Such a theory cannot be reconciled with our basic understanding of individual responsibility and blameworthiness. ${ }^{57}$

Suppose D1 and D2 jointly carry out a burglary of a house they know to be occupied. Their joint intention is that D2 should forcefully handcuff the 75-year-old occupant and give him a caning with a small light cane should he refuse to tell them where his money is hidden. D1 encourages D2 to inflict a.b.h. on 75-year-old V, if V refuses to tell them where his money is hidden, but D2 departs from the common intention and inflicts g.b.h. upon $\mathrm{V}$ by using a gun to kneecap him. (Arguably, a caning and forceful handcuffing is not likely to result in harm greater than a.b.h.) ${ }^{58} \mathrm{~V}$ is taken to hospital for treatment, but dies from complications during surgery. D2 is convicted of murder and both parties are convicted of burglary. The question then is what collateral offence, if any, should D1 be prosecuted for?

According to the decision in $R v$ Jogee and Ruddock $v$ The Queen, D1 should be liable for manslaughter. ${ }^{59}$ Complicity rests on D1 making an indirect factual contribution to D2's offence. ${ }^{60}(R v$ Jogee and Ruddock $v$ The Queen would treat the murder as a fundamentally different act and let D1 off the hook for it, but it seems to hold that an escalation of violence means D1 should be liable for a crime that could have had the same result, that is, manslaughter.) It is not a case of D1 causing the results of D2's offence or even a case of D1 causing D2 to perpetrate the anticipated target offence, because D2 causes herself to perpetrate the anticipated target crime by making the autonomous choice to perpetrate it. ${ }^{61}$ Factual participation rests on D1 assisting or encouraging D2, because it can be said that D1 in fact caused D2 to have a reason for perpetrating the anticipated target offence or that D1 caused D2 to be equipped to perpetrate the anticipated target offence. ${ }^{62}$ The culpability link is missing when D2 departs from the common intention and perpetrates an alternative offence.

The absurdity of this route to conviction is also highlighted by the fact that the accessory is held liable for a result crime such as constructive manslaughter, when there is no way of knowing, if principal had not departed from the common intention to inflict a.b.h., that the planned a.b.h. would have caused V's death. It is pure

${ }^{56}$ The change of normative position theory of criminalization is fundamentally flawed to the extent it justifies strict liability for serious crimes. For a fuller discussion of the theory, see Andrew Ashworth, 'A Change of Normative Position: Determining the Contours of Culpability in Criminal Law' (2008) 11 New Crim. L. Rev. 232.

57 See generally, Alan R. White, Grounds of Liability (Oxford: OUP, 1985); J.R. Lucas, On Justice (Oxford: Clarendon Press, 1980); Antony Duff, Answering for Crime: Responsibility and Liability in the Criminal Law (Oxford: Hart, 2007); Andrew von Hirsch, Censure and Sanctions (Oxford: Clarendon Press, 1996).

${ }^{58}$ R. v Brown [1994] 1 A.C. 212; R. v Donovan [1934] 2 K.B. 498.

${ }^{59}$ Lord Toulson has defended this position in his extrajudicial writings. See Sir Roger Toulson, 'Sir Michael Foster, Professor Williams and Complicity in Murder', Dennis J. Baker and Jeremy Horder (Eds), The Sanctity of Life and the Criminal Law (Cambridge: Cambridge University Press, 2013) at 230 et seq.

${ }^{60}$ John Gardner, 'Moore on Complicity and Causality,' (2008) 156 U. Pa. L. Rev. PENNumbra 432 at 436; Sanford Kadish, Blame and Punishment: Essays in the Criminal Law (New York: MacMillan Publishers, 1987) at 162 et passim; Michael S. Moore, 'Causing, Aiding, and the Superfluity of Accomplice Liability' (2008) 156 U. Pa. L. Rev. 395; Joshua Dressler, 'Reforming Complicity Law: Trivial Assistance as a Lesser Offence (2008) 5(1) Obio St. J. Crim. L. 427; Robert Sullivan, 'Conduct and Complicity: Liability Based on Omission and Risk' (2008) 39 Cambrian L. Rev. 60;

${ }^{61}$ Baker, above note 45 at 145-157.

62 Garnder, above note 60 . 
guesswork trying to workout whether if the principal had inflicted unlawful a.b.h. instead of inflicting g.b.h. or instead deliberately killing V, whether it would have resulted in constructive manslaughter as opposed to a conviction for assault contrary to section 47 of the $O A P A 1861$. If one were to try to estimate, the estimate would in most cases be that the a.b.h. would not cause a death.

So the encourager is held liable as an accessory for a result crime (constructive manslaughter) that was not perpetrated, based on the fiction that the result crime that was perpetrated (murder), had a consequence that could have also resulted (but was very unlikely to have resulted) from the alternative offence, if it had been perpetrated. The accessory is guilty of manslaughter based on what might have happened had the principal continued with their common plan. It is impossible to reconcile an alternative offence conviction with the mental element in complicity being nothing less than intention. It is also impossible to reconcile it with the requirement that $\mathrm{D}$ in fact assist or encourage the actual crime that was perpetrated, since an alternative crime was in fact perpetrated. (If there were no requirement of factual encouragement or assistance, then complicity liability would collapse into inchoate liability. Inchoate assistance or encouragement is criminalized under the Serious Crime Act 2007. Whatever meaning is given to the words 'aid, abet, counsel, or procure,' they have never been held to cover inchoate assistance or encouragement. ${ }^{63}$

The solution is to convict the putative accessory of trying to encourage or assist the principal to perpetrate a crime (aggravated assault contrary to section 47 of the $O A P A 1861$ is a crime per se, so it does not matter that it did not get a chance to kill $\mathrm{V}$ because it was not in fact perpetrated) contrary to section 44 or section 45 of the Serious Crime Act 2007.

It is true that an accessory can be liable for a lesser-included offence when for some reason the greater offence cannot be proved but the lesser can. A lesser-included offence is an offence for which all of the elements necessary to impose liability are also elements found in a more serious crime ${ }^{64}$ Hence, theft is a lesser-included offence for robbery, since a robbery is theft plus force. So if D1 encourages D2 to perpetrate a theft, but D2 uses force during the theft, D1 would still be liable for the theft she intentionally encouraged, but not for the robbery that she did not intend to encourage. $^{65}$

Intention is greater than recklessness and g.b.h. or death is greater than a.b.h., but the greater do not include the lesser because they are not only elements of alternative offences, but also different states of mind and different base acts of harms. Intention as the mental element for complicity precludes alternative offence liability where the lesser offence is not an included offence. ${ }^{66}$ This is also supported by the evidential maxim concerning fundamentally different acts, which is used to infer intention. Even a slightly different act (offence) rule would preclude liability if it were not a lesser-included offence, ${ }^{67}$ since there can be no derivative liability if the principal does not do what the accessory has attempted to assist or encourage, but

\footnotetext{
${ }^{63}$ R. v Jogee and Ruddockv v The Queen [2016] 2 W.L.R. 681 is categorical holding that section 8 of the Accessories and Abettors Act 1861 requires factual assistance and/or encouragement. This is also evidenced by the enactment of the Serious Crime Act 2007.

${ }^{64}$ Williams, above note 27.

${ }^{65}$ Lord Hughes and Lord Toulson provide an example of a lesser-included offence and seem not to identify the difference between included and alternative offences. 'To take a homely example, if D2 encourages D1 to take another's bicycle without permission of the owner and return it after use, but D1 takes it and keeps it, D1 will be guilty of theft but D2 of the lesser offence of unauthorised taking, since he will not have encouraged D1 to act with intent permanently to deprive.' R. $v$ Jogee and Ruddock $v$ The Queen [2016] 2 W.L.R. 681 at 706B.

66 State v. Clemons (1997) 946 S.W.2d 206; Com. v. Bachert (1982) 499 Pa. 398.

${ }^{67}$ Leavine v. State (1933) 109 Fla. 447 at 465.
} 
instead does something more serious. Section 8 of the Act of 1861 itself deems all parties to be principals on the bases that they had a shared intention with respect to the offence that was in fact perpetrated. There is nothing in that provision that allows for convictions for alternative offences, if they are not lesser-included offences. Derivate liability is available for lesser-included offences, when the accessory has intentionally assisted or encouraged them and when they have in fact been perpetrated as an included part of a greater collateral offence.

A person ought not be liable for manslaughter simply because she intended to assist and/or encourage the perpetrator to perpetrate conduct that had the potential to form the actus reus for constructive manslaughter, depending on how her moral luck might have panned out had the principal done as the accessory had attempted to encouraged her to do. The accessory did not intentionally assist or encourage the more serious offence, so she cannot be derivatively liable for it, and the perpetrator did not perpetrate the less serious offence, so there is no derivative link between the perpetrator's wrongdoing and the accessory's attempt to participate in conduct that potentially formed the actus reus for constructive manslaughter. It is best to prosecute the putative assister or encourager under sections 44 or 45 of the Serious Crime Act 2007 , for attempting to assist or encourage a potential aggravated assault. Since the a.b.h. is superseded ${ }^{68}$ by an act of killing or the infliction of g.b.h., it cannot be assumed it would have resulted in the victim being killed. Since the offences found in the sections 44 and 45 are inchoate, it is enough that the putative assister or encourager attempted to assist or encourage an aggravated assault - since that is an offence per se.

\section{The Fundamental Different Act Maxim}

In the past the fundamental different act justification has essentially been the rationale for not allowing manslaughter convictions for accessories when the principal did an act of murder and that act was a fundamental departure from the common purpose. ${ }^{69}$ In R. v Jogee and Ruddock $v$ The Queen, Lords Toulson and Hughes, said: ${ }^{.0}$

'If the principal had that intent and caused the death of another he would be guilty of murder. Another party who lacked that intent, but who took part in an attack which resulted in an unlawful death, would be not guilty of murder but would be guilty of manslaughter, unless the act which caused the death was so removed from what they had agreed as not to be regarded as a consequence of it.'

There are various formulations of this rule. It is normally couched in terms such as a 'fundamental departure' or a fundamentally different act. When the victim has been killed by the principal's act, it is often argued the death was caused by some overwhelming supervening act by the principal and thus the accessory cannot be held to have encouraged or assisted that act, because she did not intend such an act to be perpetrated as a collateral offence. The act that the accessory attempted to encourage

${ }^{68}$ R. v Jogee and Ruddock v The Queen [2016] 2 W.L.R. 681 at 707F, where Lords Toulson and Hughes accept the restraint found in the fundamental different act rule: 'The qualification to this ... is that it is possible for death to be caused by some overwhelming supervening act by the perpetrator ... of such a character as to relegate [the defendant's] acts to history; in that case the defendant will bear no criminal responsibility for the death.'

${ }^{69}$ R. v. Powell [1999] 1 A.C. 1; R. v Anderson [1966] 2 Q.B. 110 at 120 per Lord Parker CJ; R. v. Lovesey [1970] 1 Q.B. 352 at 356 per Widgery LJ.

70 [2016] 2 W.L.R. 681 at 691. 
is said to have been so different that it is relegated into the history of the matter. It is a quick fix maxim of evidence; it allows clear cases to be ruled out without too much debate. However, that does not mean borderline cases do not need careful consideration. Less clear cases will be dealt with by considering the mental element in complicity. An act might not be fundamentally different, but if it is different in that both parties did not mutually intend it as a collateral act, then only the principal will be liable for it. As we have seen above, if the change of plan results in an offence that was not a lesser-included offence being perpetrated, the accessory will not be liable for that offence unless the evidence shows she intended it to be perpetrated.

If the collateral offence that results in $\mathrm{V}$ being killed is fundamentally different from what the participants encouraged they should not be liable for either murder or manslaughter. ${ }^{71}$ Nonetheless, if D1 and D2 agree that D2 should punch V to cause V g.b.h. and D2's punch kills V, both will be liable for murder. ${ }^{72} \mathrm{D} 2$ is constructively liable because she intends to cause $\mathrm{V}$ g.b.h. and as a result (accidentally) kills V. D1 is constructively liable for the consequences of the act that she participated in through her intentional encouragement. D1 encouraged D2 to inflict g.b.h. upon V, so she is jointly and constructively liable for the unintended consequences of the aggravated assault. Constructive liability covers both the accessory and principal, because they are both culpably involved in the act that causes V's death.

Controversy arises when both D1 and D2 intend that D2 inflict g.b.h., but D2 departs from the plan to inflict g.b.h. by kneecapping $\mathrm{V}$ and instead uses fundamentally different actions/means by stabbing $\mathrm{V}$ in the throat. In R. v. Gamble, ${ }^{73}$ A1 (Douglas) and A2 (McKee) participated in a criminal joint enterprise where they agreed that P1 and P2 should inflict g.b.h. upon V, but it was agreed that the actions/means used to inflict the g.b.h. would include only a beating and a kneecapping. They agreed that a firearm should be discharged into V's limb for the purpose of kneecapping $\mathrm{V}$. The beating and kneecapping were complete before $\mathrm{V}$ was killed and therefore were separate crimes that preceded V being murdered. Douglas and McKee were involved in the precedent wounding with intent to commit g.b.h., so were jointly liable for those offences.

Douglas and McKee were not involved in the murder of $\mathrm{V}$, because they had not encouraged the act that caused V's death. P1 either suddenly formed an intention to kill or secretly harbored such an intention prior to embarking on the punishment exercise. P1 used a knife to cut V's throat and did so with such force as to cause V to die instantly. P1's act was fundamentally different from any act encouraged and authorized by Douglas and McKee. V most likely would not have died from the punishment exercise, even though there was a high risk that it could be fatal. ${ }^{74}$ Hence, the chain of causation was broken by P1's deliberate act of cutting V's throat with ferocious force. If the punishment exercise had killed $\mathrm{V}$, then all four participants would have been liable for murder. The punishment exercise did not get a chance to cause V's death, because P1 broke the chain of causation when he fundamentally departed from the plan and cut V's throat.

Arguably, what distinguishes this case is that constructive murder was replaced with murder, that is, an act of g.b.h. was replaced with an act of deliberate killing and there was no shared intention with respect to the killing as opposed to the

\footnotetext{
${ }^{71}$ This is the view endorsed by the majority in R. $v$. Rabman [2009] 1 A.C. 129.

72 R $v$ Reid (1976) 62 Cr. App. R. 109 at 112 per Lawton, L.J.

73 [1989] N.I. 268. See also R. v. Michaud (2000) 144 C.C.C. (3d) 62.

${ }^{74}$ See the observations of Lords Bingham and Roger in R. v. Rahman [2009] 1 A.C. 129 at 147; 157 respectively.
} 
g.b.h. There was a deliberate and fundamental departure from what had been mutually and conditionally intended. Lord Bingham has observed that: "Gamble and Boyd went beyond what was expressly or tacitly agreed as part of the common enterprise, with the consequence that their acts went beyond the [intentions] of Douglas and McKee and the authority given by them." 75

There is no escaping the fact that purposive killing is fundamentally different from purposively causing g.b.h. Nonetheless, the principal's secret intention to kill will not always relieve the accessory of liability. In $R$. v. Gamble ${ }^{76}$ all four participants intended to subject $\mathrm{V}$ to a punishment exercise that included a kneecapping. If the kneecapping had killed $\mathrm{V}$, then it would not have mattered that the perpetrator of the kneecapping secretly desired the kneecapping to kill $\mathrm{V}$. The kneecapping was intended and encouraged by all the participants and they all had mens rea for constructive murder, because they all at least intended the kneecapping to result in g.b.h. If the kneecapping had been the cause of V's death, there would have been no "justification for ... requiring [the jury] to consider and decide whether the principal's intent when killing the victim was the full intent to kill or the usual lesser intent to cause g.b.h. ${ }^{, 77}$ It would not have mattered in the least that some of the participants had only intended the kneecapping to cause g.b.h., because that is enough to make them constructively liable for murder. ${ }^{78}$ In such circumstances, the perpetrator's hidden agenda (fault) has no bearing on the factually encouraged act and its causal consequences, because there was a shared intention covering the act that was perpetrated. Nor does it have any bearing on the culpability manifested by the other participants who have mens rea for constructive murder, because they intended the perpetrator(s) to cause the g.b.h. that was caused.

The results/consequences distinction allows us to see that the type of action or means used to inflict the g.b.h. can make a difference to outcome liability. von Wright $^{79}$ distinguishes action from consequences in the following example: if a person opens a window the action is the opening of the window, but the result is that the window is open. In this sense the causing action of opening the window is constitutive of the conduct. Further consequences might be that the room is cooler and its occupants are now shivering. ${ }^{80}$ If we think of constructive murder, it might be done by many different types of action, but it must be intended that the action cause the result of g.b.h., even though the consequence of death is not intended.

Suppose D1 intended to encourage D2 to inflict g.b.h. with actions (means) that were not inherently likely to carry a risk of causing death, but D2 uses actions that are fundamentally more lethal. If both D1 and D2 intend to cause V g.b.h. by actions that are not inherently lethal with D2 departing from their common purpose by using inherently lethal actions to cause the g.b.h., D2 alone ought to be liable for killing V. However, technically they are both liable for constructive murder if they intended the action and its result of g.b.h., even if neither intended the consequence to be death for the victim. In such as case, both the accessory and the principal intended that the principal perpetrate the actus reus for constructive murder with the requisite fault for that offence. However, the Court and the Board have held that the accessory can be let off if the actions of the principal are a fundamental departure

\footnotetext{
${ }^{75}$ R. v. Rabman [2009] 1 A.C. 129 at 148.

76 [1989] N.I. 268.

${ }_{77}$ R. v. Rahman [2009] 1 A.C. 129 at 164 per Lord Brown.

${ }^{78}$ See R. v. Rabman [2009] 1 A.C. 129 at $167 \mathrm{G}$.

${ }^{79}$ von Wright, above note 5 at $67-68$.

${ }^{80} \mathrm{Id}$. at 90 .
} 
from what was mutually intended. ${ }^{81}$ So if D1 intends D2 to use the action (means) of beating $\mathrm{V}$ with a stick to inflict g.b.h. upon V, but D2 departs from that plan and shoots $\mathrm{V}$ in the leg thereby severing a major artery and causing $\mathrm{V}$ to bleed to death before an ambulance can arrive, only D2 will be liable for murder. Thus, the fundamentally different act maxim is no longer limited to helping juries to infer intention, but also provides a doctrinal restraint in cases where a fundamentally different action was used to inflict a result such as g.b.h. and this action has the unintended consequence of causing V's death.

An alternative solution might be to argue, as a point of evidence, the accessory only intended that the actus reus to be preformed (the action intended to result in g.b.h.) on the condition that it be performed in a non-lethal way or performed with a certain degree of risk only (i.e., with actions that are not inherently lethal). If the actions she intended to be used had been used then she would have been liable for any unintended consequences of those actions, but since inherently more dangerous actions where used, she is not liable for any offence. Hence, the accessory could argue that her intentional encouragement was conditional on the g.b.h. being inflicted without the use of inherently life-threatening actions/means. ${ }^{82}$ Arguably, the accessory's intentional encouragement was annulled because the principal did not comply with the conditions set by the accessory. The principal using inherently lethal actions and means (a gun) to cause $\mathrm{V}$ serious injury, when it has been agreed that the principal should use a stick only, would result in the accessory's conditional intentional encouragement being no encouragement at all and would be "an overwhelming supervening event which is of such a character that it will relegate into history matters which would otherwise be looked on as causative factors." $\$ 83$

For both parties to be liable for constructive murder under $R v$ Jogee and Ruddock $v$ The Queen, it will have to be proved beyond reasonable doubt that they had a shared intention that the particular act of g.b.h. that caused V's death be done by the principal in a way that was not a fundamental departure from what was intended. Presumably, where the principal departs from the plan and uses actions/means that had a similar danger level to those intended by the accessory, both will be liable. ${ }^{84}$

Nonetheless, the fact that the principal has used different actions/means to commit an offence will not relieve the accessory of liability if the accessory has encouraged the end consequence. If D1 encourages D2 to use a knife to kill a security guard for the purpose of making their joint robbery succeed, it would be no defence for D1 to argue that D2 instead used a gun to kill the guard. Nor would it matter that D1 did not know D2 was carrying a gun, because D2 has encouraged the end consequence - the murder of the guard. In this type of case, D1 does not care what actions/means are used, because she simply intends the end consequence be brought

\footnotetext{
81 R. v Jogee and Ruddock v The Queen [2016] 2 W.L.R. 681 at 707F.

82 The courts have accepted conditional intention as a limitation to approvals in other areas of the criminal law. See for example, R. (on the application of F) v. D.P.P [2014] Q.B. 581 at 588. See also Assange v. Sweden (2011) 108(44) L.S.G. 17; R. v. McNally [2014] 2 W.L.R. 200, where the courts held that consent was annulled where certain conditions were not fulfilled.

${ }^{83}$ [1966] 2 Q.B. 110 at 120. Lord Parker, C.J. goes on to observe: ' $\mathrm{T}$ f one of them ... had in a moment of passion decided to kill, [the other participants] would be acquitted altogether. ... There is nothing ... illogical in such a result, in that it could well be said as a matter of common sense that in the latter circumstances the death resulted or was caused by the sudden action of the adventurer who decided to kill and killed.' In R. v. Powell [1999] 1 A.C. 1 at 30, Lord Hutton held: 'As the unforeseen use of the knife would take the killing outside the scope of the joint venture the jury should also have been directed, as the Court of Criminal Appeal held in R. v. Anderson, that A should not be found guilty of manslaughter.'

${ }_{84}$ The courts are not likely to engage in fine line-drawing where both parties mutually intended the principal to perform the actus reus (g.b.h.) for constructive murder and where there was only a difference in label in the action used to inflict g.b.h. as opposed to a difference in gravity and substance in the action used.
} 
about by whatever actions/means are available. This important distinction was overlooked in R. v. Williams, ${ }^{85}$ where Smith, J.A said: 'If the object or purpose of the counseling is achieved in substance the means used by the principal to achieve it is usually irrelevant on the question of the liability of the accessory. .... If it was found that what was desired and expressed was that serious bodily injury should be inflicted, then whatever means were employed by Blackwood to effect that desired end would be within the ambit and scope of the counseling.'

This reasoning is harsh in the context of constructive crimes, because the end crime depends on moral bad luck. One can encourage an act that is not likely to be morally as unlucky as some other act. Williams had only encouraged Blackwood to cause V serious injury by beating V. Williams had not asked Blackwood to use means that posed a real risk of causing the victim's death. Blackwood stabbed V in the neck, which is an act that is fundamentally different from beating a person with bare fists. It is one thing to encourage a wounding (a stabbing in a delicate place such as a neck) and another to encourage a beating with bare fists.

If Williams had encouraged Blackwood to use a knife to wound $\mathrm{V}$, then both should have been liable for the consequences of the act they jointly intended. Furthermore, if the beating by bare fists alone had killed V, then both should have been liable for murder. ${ }^{86}$ On the facts of the case, Williams should have been liable only for the aggravated assault that preceded the wounding. If Williams had asked Blackwood to murder $\mathrm{V}$, then the means used would have been irrelevant, because Williams would have encouraged Blackwood to perpetrate a particular result crime.

\section{The Culpability Gap and Semi-Innocent Agents}

Even voluntary manslaughter is not a lesser-included offence of murder because murder has the extra elements of an intention to cause g.b.h. or death, but the doctrine of semi-innocent agency ${ }^{87}$ might allow for a murder conviction for the putative accessory in cases where the accessory uses a semi-innocent agent to kill. ${ }^{88}$ On these facts, the putative accessory would be liable for the greater crime of murder, and the perpetrator for the lessor crime of manslaughter. ${ }^{89}$ However, criminal liability in such a case does not rest on derivative liability, since the greater state of mens rea of the user of the semi-innocent agent cannot derive from her intending that the semiexcused agent act with a lesser state of mens rea. A fortiori when the semi-innocent agent does in fact act with a lesser degree of fault; a person cannot be liable for intentionally assisting or encouraging her to act with a greater degree of fault. The culpability gap between the principal and accessory is plugged by invoking the doctrine of semi-innocent agent to cover any part of the mental element of the greater

\footnotetext{
85 (1973) 21 W.I.R. 329 at 338; 340 per Smith, J.A (Henriques, P., and Hercules, J.A. concurring).

86 Cf. R. v. Creamer [1966] 1 Q.B. 72.

${ }^{87}$ See Glanville Williams, Textbook of Criminal Law (London: Stevens \& Sons, 1983) at 373 discussing R $v$ Richards [1974] QB 776. See also David Lanham, ‘Accomplices, Principals and Causation’ [1980] 12(4) Melb. U. Law Rev. 490.

${ }_{88}$ The semi-innocent agency doctrine received some support in R. v Howe [1987] A.C. 417. The case is straightforward when the agent is fully innocent. See R. $v$ Saunders (1577) 2 Plow. 473.

${ }^{89}$ R. v Manley (1844) 1 CoxC.C. 104; People v Hallett (1979) 419 NYS 2d 397 (perpetrator's youth); State v Lord (1938) 42 N.M. 638; State v McAllister (1978) 366 So 2d 1340 (perpetrator provoked). See also Matthew Hale, The History of the Pleas of the Crown, (London: Printed by E. and R. Nutt et al., 1736) Vol. I at 434. Hawkins seems to accept the innocent agency doctrine, see William Hawkins, $A$ Treatise of the Pleas of the Crown, (London: Printed by $\mathrm{E}$ and $\mathrm{R}$ Nutt, et al, 1734), Vol. I, at Chap. 29, Sect. 7. However, Hawkins also expounds: 'Whether the offence of the accessary can ever rise higher than that of the principal. I take it to be an uncontroverted rule, that it never shall; it seeming incongruous and absurd that he who is only as a partaker of the guilt of another, should be adjudged guilty of a higher crime than the other.' Id. Chap. 29, Sect. 15.
} 
crime where the principal was innocent, but where the accessory had the requisite fault.

So if D1 has a hidden intention, she can be liable for murder and D2 for manslaughter. There is no doubt that if D1 encourages D2 to do act $x$ that both D1 and D2 will be liable for, $y$, the causal consequences of act $x$. Let us assume act $x$ is intended to be an act of unlawful a.b.h., and consequence $y$ is that $\mathrm{V}$ dies as a result of the a.b.h. On these facts, D1 and D2 are both liable for constructive manslaughter. ${ }^{90}$ The only circumstances where D2 might be liable for murder while D1 remains liable for manslaughter only, would be where the act (a.b.h.) that causes V's death is mutually intended, but where D2 intends the a.b.h. to kill V. Suppose that D1 knows that $\mathrm{V}$ has a special vulnerability (thin skull) and intends to make use of it to achieve her end of killing V. For example, assume D2 does not know that V suffers haemophilia, but D1 does. D1 gives D2 a knife so that D2 can give V a very trivial surface wound. D2 merely intends to cause V a.b.h., but D1 intends to make V bleed to death. ${ }^{91}$ Here the semi-innocent agent doctrine would plug the culpability gap and perpetration gap, because it would deem D1 a perpetrator of the greater offence and D2 a perpetrator of the lesser offence. It is the semi-innocent agent doctrine that makes liability possible in such cases, not derivative liability, because the secondary party's culpability derives from her intending the principal to act with the requisite fault that she is also held liable for. In the hypothetical just given, D2's fault does not extend beyond constructive manslaughter, since she intended a.b.h. only.

Contrast the above scenario with a case where D1 encourages D2 perpetrate act $x$ secretly intending act $x$ (a kneecapping) to kill $\mathrm{V}$ knowing that D2 only intends act $x$ to cause $\mathrm{V}$ g.b.h. Both D1 and D2 will be liable for murder, since D1 intends to encourage D2 to perpetrate murder and D2 intends to perpetrate the actus reus of murder (intentional g.b.h. resulting in V's death) with the requisite fault for murder. It does not matter that D2 is only constructively liable for murder, because the very act of g.b.h. (the kneeapping) that they both intended to be perpetrated caused V's death. $^{92}$

In certain cases, it might be permissible to convict one party of murder and the other of gross negligence manslaughter, but only where they have been joint perpetrators of the act that caused V's death. ${ }^{93}$ Suppose D1 mistakenly assists D2 to kill. Take the example where D2 knocks V unconscious and thereafter asks D1 to help her to dispose of V's (live) body by throwing it from a cliff into the ocean. ${ }^{94} \mathrm{D} 2$ does not tell D1 that V is merely unconscious. Instead, she tells D1 that V is dead and that she needs to dispose of V's body before her murderous act is discovered. D1 helps D2 to dispose of $\mathrm{V}$ by jointly perpetrating the act of throwing $\mathrm{V}$ over the cliff. However, this is a case of joint perpetration of the actus reus were the parties have different states of fault. It might be argued that it is grossly negligent to drop a human over a cliff without knowing for certain that she is dead, if a reasonable person would foresee that she might be alive and that such an act is highly likely to kill her. ${ }^{95}$

The semi-innocent agent cases will be limited in homicide cases to those where the principal can rely on the partial defences of diminished responsibility or loss of control. More generally, such cases will be limited to facts where the agent-

\footnotetext{
90 R. v Creamer [1966] 1 Q.B. 72; R. v Buck (1960) 44 Cr. App. R. 213.

91 State v. Frazer (1936) 98 S.W.2d 707; Burrage v. U.S. (2014) 134 S.Ct. 881 at 888.

${ }^{2}$ R. $v$ A [2011] Q.B. 841; R. v. Rahman [2009] 1 A.C. 129.

93 Baker, above note 4 at 147 et seq.

${ }^{94} \mathrm{D} 1$ would be liable for her personal fault, which involves her putatively perpetrating offences relating to the disposal corpses and so on.

95 Attorney-General's Reference (No.4 of 1980) [1981] 1 W.L.R. 705; cf. R. v. Adomako [1995] 1 A.C. 171.
} 
user hides an essential fact from the principal thereby causing the principal to genuinely believe that her wrong is less dangerous than it is and that she is perpetrating some lesser offence and vice versa. In some cases, it will be the accessory with a lower level of fault, not the principal. ${ }^{96}$ The semi-innocent agent doctrine can work only if we treat both parties as joint perpetrators (D1 is a semiinnocent perpetrator, and D2 is fully culpable constructive perpetrator) of the actus reus of voluntary manslaughter, the intentional and voluntary killing of another human being. Arguably, they are both perpetrators of same actus reus and have the same fault (an intention that $\mathrm{V}$ be killed), but one has a partial excuse which reduces her fault allowing her to reduce her murder conviction to manslaughter.

The problem with this rationalization for holding the parties liable for crimes of different degrees is that it is conceptually messy, since it imputes perpetration in reverse order to the respective parties in proportion with culpability. The doer is personally liable for manslaughter, since she has killed with the requisite fault for manslaughter. Since the doer's fault does not extend to murder, she is not regarded as a perpetrator of murder. Instead, the putative accessory (the encourager/assister) is deemed to have used an innocent agent to perpetrate murder, but the innocent agent is personally liable for everything below murder where she was not innocent. In effect, it is just a roundabout way to hold the putative accessory liable for a greater crime, because her fault was personal for the part of the crime that made it murder for her rather than mere manslaughter. It is somewhat fictitious to hold that the putative accessory perpetrated murder, when the act of killing was perpetrated by the perpetrator, simply because the putative accessory had the requisite men rea for murder while the perpetrator of the act that caused V's death had mens rea only for manslaughter.

It is not the best solution to invoke the semi-innocent agent doctrine in such cases, because the doctrine is a conceptually messy way to try to find an exception to straightforward derivative liability. The better solution is to convict the putative accessory of trying to encourage or assist the partially excused (innocent) agent to perpetrate an offence contrary to section 44 of the Serious Crime Act 2007. Such an approach would be easier to apply in practice and would avoid the complexity of treating both parties as joint perpetrators with different levels of culpability and as having acted as perpetrators to different degrees. The fact that the D1 was trying to encourage D2 to perpetrate a more serious offence such as murder instead of manslaughter, could be taken into consideration by the sentencing judge when sentencing D1 for contravening section 44. D2 would simply be liable for manslaughter. The objection would be that the section 44 crime label does not reflect that D1 is essentially the constructive perpetrator of murder. ${ }^{97}$

Nonetheless, if D1 encourages D2 and D3 to inflict g.b.h. upon her husband, but D2 and D3 secretly only intend to inflict a.b.h. and in fact only inflict a.b.h., D1 cannot be liable for the offence of inflicting g.b.h. contrary to section 18 or 20 of the

\footnotetext{
${ }^{96}$ R. v Marks [1998] Crim. L.R. 676 at 678, where J. C. Smith comments 'A person who is provoked into doing acts encouraging or assisting the commission of murder is guilty of that offence, no less than the principal, unless he can invoke the defence. ... If the acts of Thomas Becket (saints can be infuriating) were sufficient to cause a reasonable twelfth century king to lose control and exclaim, "Who will rid me of this turbulent priest?" Henry II ought to have had a defence if he had been charged with murder (inconceivable of course) when the four gallant knights duly obliged their monarch and murdered the unfortunate Archbishop. The converse case may also occur, i.e. the killer, being provoked, is guilty only of manslaughter, but the unprovoked instigator is guilty of murder through a semi-innocent agent.'

97 Cf. the discussion in Kadish, above note 60 at 181-186.
} 
Offences against the Person Act 1861, because no such offence has been perpetrated. $^{98}$

\section{Conclusion}

The upshot of the ruling in $R v$ Jogee and Ruddock $v$ The Queen, that the mental element in complicity is intention, is that to be guilty of intentional murder as an accessory, the accessory must have intended for the victim to be killed or suffer g.b.h. In $R v$ Jogee and Ruddock $v$ The Queen, Lords Toulson and Hughes held that an accessory can be held liable for manslaughter when the principal has been convicted of murder, as long as she was involved in a joint attack where some harm, albeit not serious harm, was likely to result from the acts of violence that she was attempting to encourage. This is difficult to reconcile with the intention requirement that has now been recognised as the mental element in complicity. It is one thing to hold the accessory and the perpetrator liable for murder when the evidence shows they had a shared intention that the principal perpetrate a particular act of g.b.h. (e.g. their shared intention was that the principal would stab $\mathrm{V}$ in the back) and that very act kills $\mathrm{V}$, but something conceptually different to hold an accessory liable for an alternative crime of manslaughter simply because she was present attempting to encourage the principal to perpetrate an act that might have resulted in them both being convicted of constructive manslaughter had that act been done instead of the act of g.b.h. Murder requires an intention to kill or cause g.b.h., so if the principal intends to kill or cause g.b.h. and accessory only intends the principal to cause a.b.h., there is no shared intention with respect to a core element of the crime of murder. Since manslaughter is not a lesser-included offence, it is not possible for a person to be derivatively liable for it when the crime that has in fact been perpetrated was murder.

It also was argued above that $R v$ Jogee and Ruddock $v$ The Queen supports holding that there should be a shared intention with respect to the type of g.b.h. caused or at least to the actions/means used to cause it. This is a qualification to the strict intention requirement, because it means in the case of constructive murder the defendant will not be liable simply because there was a shared intention that a collateral crime involving the infliction grievous bodily harm be perpetrated. Instead, it will have to be shown that the action or means used to inflict the g.b.h. was not a fundamentally different action or means than the accessory intended the principal to use. This will be particularly pertinent, when the principal has used actions or means that were inherently more lethal (dangerous) than those the accessory intended her to do or use. It also means the putative accessory cannot be liable for manslaughter.

If the accessory intends to encourage the principal to perpetrate an act (a.b.h.) that might result in them both being convicted of manslaughter should the victim be killed, but when principal departs from the plan and takes it upon herself to perpetrate an act of g.b.h., the accessory should be charged under section 44 of the Serious Crime Act 2007 for attempting to encourage principal to perpetrate an aggravated assault contrary to section 47 of the Offences against the Person Act 1861, because that is all she does. Direct intention as the mental element in complicity means that the accessory can be liable only for the principal's crimes when she intended the principal do the requisite actus reus for the relevant crime with the requisite fault.

\footnotetext{
${ }_{98}$ Cf. R. $v$ Richards [1973] 3 W.L.R. 888 which was technically not overruled by R. $v$ Howe [1987] A.C. 417, because R. v Howe simply supports the semi-innocent agency doctrine. Richards was not a semi-innocent agent, she was exempt from liability for the more serious crime because it was not in fact perpetrated.
} 
There must be a shared intention with respect to the actus reus perpetrated by the principal and with respect to the principal's requisite fault for that act.

The semi-innocent agent doctrine might justify alternative convictions of manslaughter and murder in very rare cases where the principal is personally liable for manslaughter and where the secondary party's higher level of fault means she used an innocent agent to perpetrate a greater crime such as murder. Such cases are likely to be rare, because they will only arise where something is hidden from the doer or the doer acts due to a loss of control or diminished responsibility. Similarly, if the assister or encourager has a partial excuse or innocently assists or encourages a part of the crime. It was argued above, that given the conceptual weakness and messiness of this approach, it might be better to rely on the Serious Crime Act 2007 to convict in cases where there are different degrees of fault and where some of the perpetration is imputed to the principal and some to the agent who uses the principal to ensure a more serious crime than the principal intended is perpetrated. 